\title{
New genus and species of broad-nosed weevils from Baltic amber and notes on fossils of the subfamily Entiminae (Coleoptera, Curculionidae)
}

\author{
Nikolai N. Yunakov ${ }^{1,2, \dagger}$, Alexander G. Kirejtshuk²,,ł \\ I Natural History Museum, University of Oslo, P.O. Box 1172 Blindern NO-0318 Oslo, Norway 2 Zoological \\ Institute, Russian Academy of Sciences, Universitetskaya nab. 1, St. Petersburg, 199034, Russia 3 Muséum \\ National d'Histoire Naturelle, CP 50, Entomologie, 45 Rue Buffon, F- 75005 Paris, France \\ † urn:lsid:zoobank.org:author:62A12A2F-F00D-4E7C-88BA-252EA7A1DEB9 \\ † urn:lsid:zoobank.org:author:D63E800C-87F6-4281-8658-C3C032FE8628
}

Corresponding author: Nikolai N. Yunakov (n.yunakov@gmail.com)

Academic editor: M. Alonso-Zarazaga | Received 16September 2011 | Accepted 7 December 2011 | Published 29 December 2011

urn:lsid:zoobank.org:pub:C7EF821A-79AF-4DB0-A059-E59CCCE93DBC

Citation: Yunakov NN, Kirejtshuk AG (2011) New genus and species of broad-nosed weevils from Baltic amber and notes on fossils of the subfamily Entiminae (Coleoptera, Curculionidae). ZooKeys 160: 73-96. doi: 10.3897/zookeys.160.2108

\begin{abstract}
Arostropsis groehni gen. et sp. n. is described from Baltic amber and temporarily placed in the tribe Naupactini. It differs from all recent Naupactini genera with open corbels by very short and flattened scape, distinct lateral carina of the pronotum and elytra, and the rostrum distinctly narrower than the head capsule. The shape of head in the extinct genus is somewhat similar to that of the extant Naupactini genera with enclosed corbels (Platyomus Sahlberg, 1823 and Aptolemus Schoenherr, 1842), but differs in the slender body, open corbels, very short antennal scape and epifrons without a median sulcus (only a longitudinal depression is slightly visible). It is also similar to the Tanymecine genus Pandeleteius Schoenherr, 1834 in general appearance, but distinct by the straight anterior edge of the pronotum, lack of postocular spurs, lobes, and vibrissae, a slightly sloping elytral declivity, lateral ridges on the pronotum, subflattened antennal scape, elongate rostrum, and sparsely setose epistome. A new synonymy of the generic names Protonaupactus Zherikhin, 1971 and Sucinophyllobius Wanat \& Borowiec, 1986, syn. n., is established. The Madagascan genus Corecaulus Fairmaire, 1903 is transferred from the tribe Naupactini to the Brachyderini because of its connate claws and the similarity in chaetotaxy of the epistomal area with African and Madagascar Brachyderini genera. A key to the identification of known Baltic amber genera of Entiminae is proposed. A checklist of the prepleistocene fossil Entiminae, based on V.V. Zherikhin's data, with remarks and corrections, is presented.
\end{abstract}

Copyright N.N.Yunakov, A.G. Kirejtshuk. This is an open access article distributed under the terms of the Creative Commons Attribution License 3.0 (CC-BY), which permits unrestricted use, distribution, and reproduction in any medium, provided the original author and source are credited. 


\section{Keywords}

new genus and species, new synonymy, fossil Entiminae, Naupactini, Baltic amber, key, checklist

\section{Introduction}

Having examined the Baltic amber weevils from the collection of Mr. Carsten Gröhn, a new genus and species belonging to the subfamily Entiminae is described. However its tribal attribution was questioned because of the aberrant shape of the head capsule and inaccessibility of structures normally used for diagnostics (e.g. genitalia). In studying the various characters of Entiminae weevils, it became readily apparent that one of the most useful diagnostic features at the suprageneric level is the structure of the mandibular processes. They show some variability within Entiminae in general, but within certain tribes is usually rather stable. Besides, the mandibular process of fossils can be used, if available, as an additional character for identification of tribes.

In the course of the current study, mandibular processes of 35 extant genera in 17 tribes, including 6 genera of the tribe Naupactini Gistel, 1848, were examined (results of this comparison will be published in a forthcoming paper).

In addition, non-American genera treated in the Naupactini were also examined. As a result, the Madagascar genus Corecaulus Fairmaire, 1903 (type, female examined, MNHN) was transferred from the tribe Naupactini to Brachyderini, as its claws are connate in the basal third and similar to those in the genera Podionops Schoenherr, 1847 (South Africa) and Lagocaulus Fairmaire, 1903 (Madagascar) with the long median sulcus at the vertex and chaetotaxy of the epistomal area.

The type specimens of some poorly known taxa were re-examined. Phyllobius sobrinus Voss, 1972 was placed in the genus Sucinophyllobius (Wanat and Borovec 1986). A redescription of Protonaupactus is provided and a new taxonomic placement is proposed for this genus in accordance with the current knowledge of the Tertiary Entiminae fauna (Zherikhin 1971, 1992; and original data). This new information is included in the online catalogue (Ponomarenko et al. 2011).

\section{Historical review of fossil Entiminae}

The earliest descriptions of fossils from the subfamily Entiminae Schoenherr, 1823 were published by Heer (1847), Germar (1849), and Giebel (1856) in their reviews of "Tertiary" insects. One of the preceding publications includes a brief note on unrecognizable "Naupactus" species (Serres 1829). These authors assigned fossil species to recent genera. The oldest species treated as Entiminae (Sitonites melanarius) was dated from the Upper Jurassic (Heer 1864), but this assignment with the broad-nosed weevils is rather doubtful and it is not considered reliable. The fossil specimens reliably identified as Entiminae originated from the Middle Eocene 
(Green River and Roan Mountain), the boundary between the Eocene and Oligocene, and also from the Lower Oligocene (Florissant and White River) (Scudder 1893). Exclusively rich American deposits with 47 genera and European deposits with 11 genera demonstrate the level of the Caenozoic diversity of this subfamily. The Middle Eocene deposits contain taxa resembling Entiminae but bear no mandibular processes, such as in Aterpini Lacordaire, 1866, usually assigned to the subfamily Cyclominae Schoenherr, 1826 (Oberprieler 2010). Some advanced genera of Entiminae have also been found with well developed postocular vibrissae and mandibles bearing mandibular processes, which are usually treated as members of the tribes Tanymecini Lacordaire, 1863 and Ophryastini Lacordaire, 1863. A rather large number of the taxa with free claws in the Caenozoic fossil weevils could be regarded as remarkable. Unfortunately, poor preservation of weevils from the Green River and most other American sediments make it difficult to determine generic or even tribal attributions, as most important characters (particularly legs and thin structures of the rostrum) seem to be rarely available for study. On the other hand, good preservation of some compression remnants makes it possible to provide precise systematic interpretations. In particular, the inprints of Geralophus fossicius Scudder, 1893 from Florissant, initially treated as Alophini LeConte, 1874, have the distinct transverse sulcus at the base of the epifrons, and the latter was transferred to Cylydrorhinini Lacordaire, 1863 or Aterpini (Cyclominae) (see Scudder 1893: plate II, Figs 16, 17 and 24); however, a more precise placement is scarcely possible due to the masking of fine structures of the mouthparts and epistomal area of the rostrum. Most Entiminae described from the Upper Eocene resin of Denmark, Poland and Russia (Voss 1953, 1972; Zherikhin 1971; Wanat and Boroviec 1986) are in quite good condition.

\section{Baltic amber Entiminae and their systematic and biographic links}

The Baltic amber weevils apparently share more similarity with recent groups occurring mostly in the Indo-Malayan (Oriental) and Neotropical Regions (Zherikhin 1971). The biotic similarity could be due to the more homogeneous Paleogene Euro-Asian biota which now mostly remains in the recent "Himalayan-Burmanian-Yunannian block" (Takhtajan 1970; Kirejtshuk and Kurochkin 2010), but the link between this Paleogene biota with the recent Neotropical fauna is still unclear. Nevertheless, the Baltic amber fauna of Entiminae comprises two fossil genera, Paonaupactus Voss, 1953 and Protonaupactus Zherikhin, 1971, linked to the Neotropics, versus Sucinophyllobius Wanat \& Boroviec, 1986, linked to the Indo-Malayan Region. Polydrusus Germar, 1817 , is the only confirmed recent genus known from Baltic amber. It was established by the paleoendemic, monotypic subgenus Palaeodrosus Zherikhin, 1971, and is highly diverse in the recent fauna of the warm-temperate zone of the Palaearctic where it comprises 204 species. Another recent Palaearctic genus recorded from Baltic amber may be Trachyphloeus Germar, 1824 (Klebs 1910), but this data is still not confirmed. 
The genus Paonaupactus Voss, 1953 is monotypic and it is considered as a member of the tribe Anypotactini Champion, 1911 (Alonso-Zarazaga and Lyal 1999). Protonaupactus Zherikhin, 1971 is also monotypic and it was originally placed in the tribe Naupactini Gistel, 1856). The genus Sucinophyllobius Wanat \& Boroviec, 1986 was proposed for Phyllobius sobrinus Voss, 1972 and another species (Sucinophyllobius viridis Wanat \& Boroviec, 1986) was also described in it. According to the recent catalogue of weevil genera (Alonso-Zarazaga and Lyal 1999), Sucinophyllobius belongs to the tribe Cyphicerini Lacordaire, 1863. Preliminary study and a comparison of Sucinophylobius with Cyphicerus reveals that the characters of the head and prothorax make it questionable if Sucinophyllobius belongs within the subtribe Cyphicerina (see further discussion below under Protonaupactus).

\section{Methods}

The usual optic equipment was used for descriptions, including a Leica MZ 16.0 microscope provided with a CCD camera and camera lucida. Morphological terms mostly follow Thompson (1992), Emden (1944), and Doyen (1966). Special terms related to the rostrum structure follow Oberprieler 1988 and details of the epistomal area follow Morimoto et al. (2006).

Measurements. All measurements were taken with an ocular-micrometer. Body length was measured from the anterior margin of the eyes to the apex of the elytra, and rostrum length from the rostrum apex to the anterior margin of the eyes. Width of the rostrum is the maximum distance between the lateral edges of the pterygia.

Imaging. All outline illustrations were drawn using a camera-lucida and modified with a Wacom Graphire 4 Classic XL A5 tablet in Corel Draw (version 11.633) Corel ${ }^{\circ}$. Merging of layers was done with Helicon Focus (version 5.0) HeliconSoft ${ }^{\circ}$. Amber samples were photographed as under normal conditions as well as in sugar syrup to provide more suitable light refraction.

Abbreviations of depositories. GPIH Institute of Geology and Palaeontology and Museum (Geologo-Paläontologisches Institut u. Museum), University of Hamburg; MNHN National Museum of Natural History (Museum National d'Histoire Naturelle), Paris; ZMUC Zoological Museum (Zoologisk Museum), University of Copenhagen.

Abbreviations of morphological terms. cb corbel, es epistomal setae, ed elytral declivity, fr frons, hp humeral prominence, ibt intero-basal tooth, ma mandibular process, lr lateral ridge of pronotum, pep parepistome.

Abbreviations in table. Agri Agriento (=Girgenti), Sicilia, Italy, Upper Miocene; Aix Aix-en-Province, France, Lower Oligocene; BalJ Baltic Amber, Baltic and North Sea coast, Upper Eocene; Boet Böttinger Marmors, Germany, Miocene; Cere Céreste, west to Apt, Alpes-de-Haute, Basses Alp Department, Provence, France, Lower Oligocene; Cela Célas, railway Uzés - Saint-Julien-de-Casignac, Fumades, Corents, Bassein Ales, Gard Dept., France, Upper Eocene, previously Lower Oligocene (San- 
nosien); Dece Lava Camp Mine, Jumachuk River Valley, Seward peninsula, Alaska, Pleocene-Pleistocene (5.7 mln - 27000 - Deceit Formation); DomJ Dominican amber, Dominican Republic and Haiti; Lower Miocene; CerG Cerro Guido, Ultima Esperanza, Magallanes, Upper Cretaceous; Core Corent, Gergovia Plateu, south of Clermon-Ferran, Puy-de-Dom Department, France, Upper Oligocene; Flor Florissant, south fork of Twin Creek, Front Range near Pike's Peak, Colorado, U.S.A., Lower Oligocene. GreR Green-River, 3-4 km western rail-way crossing of Green River; Utah, U.S.A, Middle Eocene; N1 Neogene, Miocene; N11 Neogene, Lower Miocene; N13 Neogene, Upper Miocene; N2 Neogene, Pliocene; K2 Upper Cretaceous; Dece Lava Camp Mine, Jumachuk River Valley, Seward peninsula, Alaska, Pleocene-Pleistocene site (5.7 mln - 27000 - Deceit Formation); Oeni Oeningen, near Baden lake, BadenWürttemberg, Germany, Upper Miocene; Pg12 Paleogene, Middle Paleocene; Pg2 Paleogene, Eocene; Pg22 Paleogene, Middle Eocene; Pg23 Paleogene, Upper Eocene; Pg31 Paleogene, Lower Oligocene; Pg33 Paleogene, Upper Oligocene; RoaM Roan Mountain, Colorado, USA, Middle Eocene; Rott Siebengebirge, Germany; Lower Miocene, Aquitanian or Upper Oligocene; Sunc Sunchal, La Mendieta, Jujuy Prov., northern Argentina; Upper Paleocene (Lower Eocene); WhiR White River Badlands, South Dakota, boundary Eocene and Oligocene.

\section{Taxonomic treatment}

Order Coleoptera Linnaeus, 1758

Family Curculionidae Latreille, 1802

Subfamily Entiminae Schoenherr, 1823

Arostropsis Yunakov \& Kirejtshuk, gen. n. urn:lsid:zoobank.org:act:24BF76B1-8ADA-44BA-B111-FEED72EB7A05 http://species-id.net/wiki/Arostropsis

Type species. Arostropsis groehni Yunakov \& Kirejtshuk, sp. n.

Etymology. The name of the new genus is formed from the Greek negative prefix "a", "rōstron" (beak, bill, snout) and "opsis" (resembling a (specified) thing). Gender feminine.

Diagnosis. Body elongate, in general appearance similar to Pandeleteius Schoenherr, 1834. Antenna with scape short, as long as pedicel (first funicular article; term after Doyen, 1966) and $2^{\text {nd }}$ funicular article (antennomere 3 ) together, reaching anterior margin of eye, strongly widened and flattened dorso-ventrally along apical third. Rostrum distinctly elongate and slender, about half as thick as frons. Vertex with small frontal fossa anterior of eyes. Buccal cavity completely covered by prementum; transverse sulcus absent. Epistome sparsely setose: only two pairs of short (internal) and long (external) setae (such composition of setae is not found among groups of Naupactini and Anypotactini); parepistome (term after Morimoto et al. 2006) weakly acute and 
gently extending beyond contour of rostrum (Fig. 14). Antennal scrobes entirely lateral, just swinging fossa (term after Morimoto et al. 2006) slightly visible from above, pterygia scarcely pronounced. Mandibular process resembling that in other Naupactini (this structure was examined for six genera of Naupactini), weakly curved inward, with distinct dorsal carina, without inner basal tooth (Fig. 18). Eyes strongly asymmetrically convex. Pronotal and elytral disk distinctly depressed dorsally. Pronotum with distinct lateral ridges; its posterior edge bisinuate. Elytra subparallel-sided, with humeral and distinct subapical prominences, elytral declivity gently sloping. Femora obtuse, weakly swollen. Metatibiae with open corbels. Claws free.

\section{Arostropsis groehni Yunakov \& Kirejtshuk, sp. n.} urn:Isid:zoobank.org:act:25FBCC0C-8376-41C7-A86E-F024B1541EEC http://species-id.net/wiki/Arostropsis_groehni

Figs $1-16$

Material examined. Holotype "C 7968, GPIH 4516", male (GPIH); the complete beetle with a clear integument is included in an irregular parallelepiped with the largest plane about $18.0 \times 14.0 \mathrm{~mm}$ and the smallest one $11.0 \times 7.0 \mathrm{~mm}$; amber matter on right side from the beetle is rather homogeneous, but that from the left side of the inclusion consists of some layers, in which between the borders is a fine net of dark (almost blackish) organic matter.

Etymology. The epithet of the new species is formed from the name of Carsten Gröhn, collector of its holotype.

Type strata. Baltic Amber; Upper Eocene, Prussian Formation.

Type locality. Baltic Sea coast and Amber quarry Jantarny near Kaliningrad (formerly Koenigsberg), Kaliningrad region, Russia.

Description. Length 6.4, width 1.8, height $1.3 \mathrm{~mm}$. Body slender, distinctly depressed from above. Pronotum and elytra strongly carinate at sides. Integument densely covered with small, apparently metallic, lanceolate (apparently green) scales at both sides of body and legs.

Head. Rostrum 1.5 times as long as wide, narrow, distinctly narrower than head capsule, laterally depressed. Pterygia weakly extending beyond lateral contour of rostrum. Epistomal area not depressed. Lateral edges of epifrons at middle convex, narrowed towards middle, then parallel-sided, without basal, transverse depression or sulcus. Median sulcus shallow, extending towards pit between eyes, not continuing towards vertex. Head capsule not constricted beyond eyes. Frons distinctly convex, almost twice as wide as epifrons at level of antennal insertions. Maximum width of head at posterior part of eyes. Scape comparatively short, about $1 / 4$ as long as funicle, strongly expanded apically, somewhat compressed dorsoventrally, not extending beyond anterior third of eyes, directed obliquely downwards in folded state. Funicle slender; all segments elongate, funicular segment 1 about three times as long as wide, $2^{\text {nd }}$ about two times as long as wide, $3^{\text {rd }}$ about 1.5 times as long as wide; $4^{\text {th }}-5^{\text {th }}$ about two times as long as wide, segments 

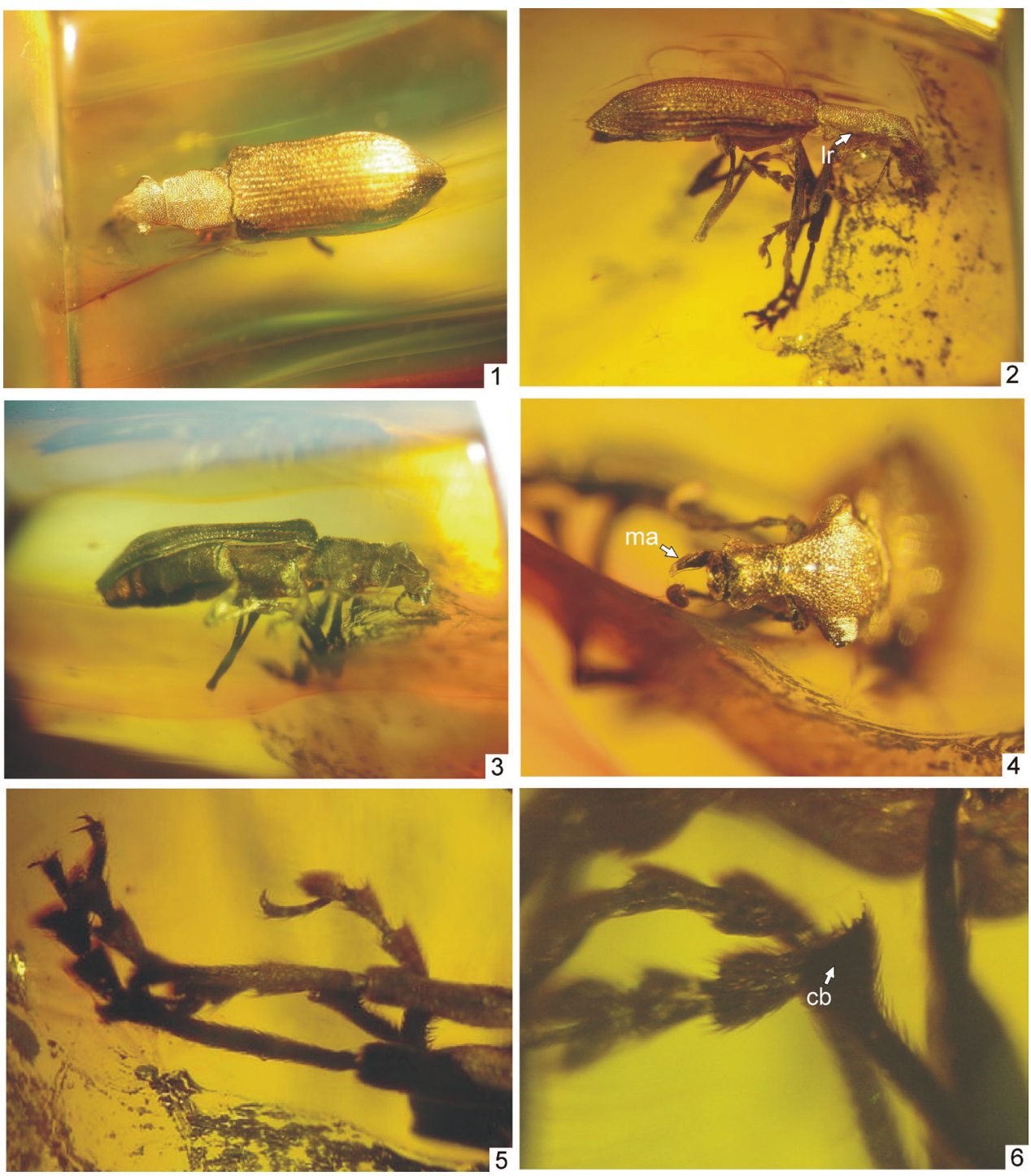

Figures I-6. Arostropsis groehni gen. et sp.n. I body, dorsal view $\mathbf{2}$ body, lateral view $\mathbf{3}$ body, ventrolateral view $\mathbf{4}$ head, dorsal view $\mathbf{5}$ protarsi $\mathbf{6}$ metatibia apex. Abbreviations: $\mathbf{c b}$ - corbel, ma - mandibular process. Body length: $6.4 \mathrm{~mm}$.

6-7 about 1.5 times as long as wide. Club spindle-shaped and comparatively thin, with distinctly separated segments, about as long as funicular segments 1-7 together. Mandibles entirely bare (without scales), moderately extended beyond buccal cavity. The only remaining left mandibular process knife-shaped, in apical third slightly curved inward, without internal prominences, about 1.5 times as long as protruding part of mandibles.

Pronotum elongate, almost parallel-sided, with anterior and posterior constrictions widely expressed, weakly and evenly convex at sides, with disc weakly convex transverse- 


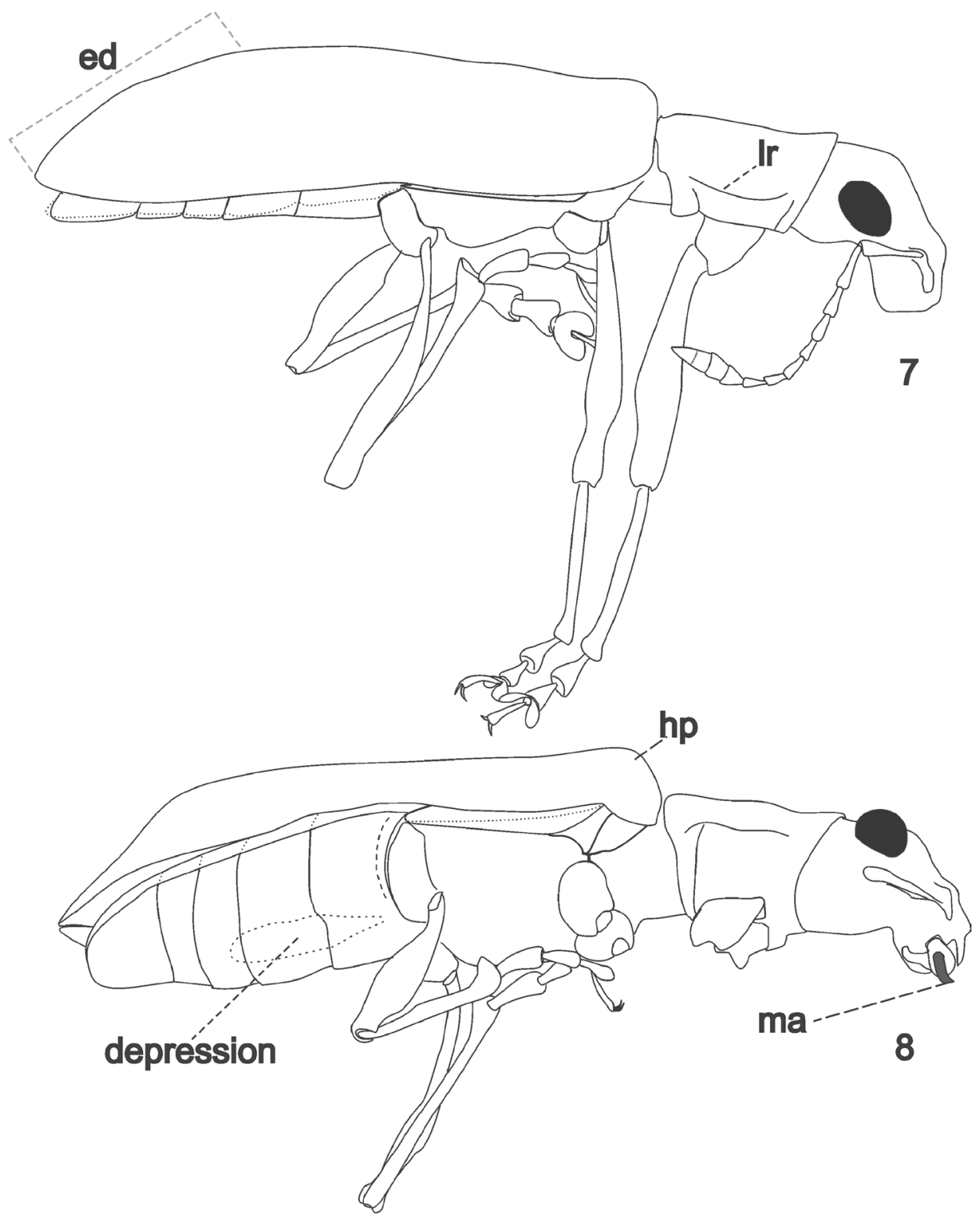

Figures 7-8. Arostropsis groehni gen. et sp.n. 7 body outline, lateral view 8 idem, ventro-lateral view (anterior and middle limbs removed). Abbreviations: ed elytral declivity, hp humeral prominence, lr lateral ridge, ma mandibular process. Body length: $6.4 \mathrm{~mm}$.

ly and anterior edge curving upward; posterior edge slightly bisinuate; posterior angles widely rounded and somewhat projecting posteriorly; anterior edge nearly straight.

Elytra elongate, about 4.5 times as long as wide, parallel-sided, humeral prominences distinct (Fig. 8, hp), basal edge of elytra biconvex opposite the posterior pronotal depressions. Elytral declivity gently sloping (Fig. 7). 

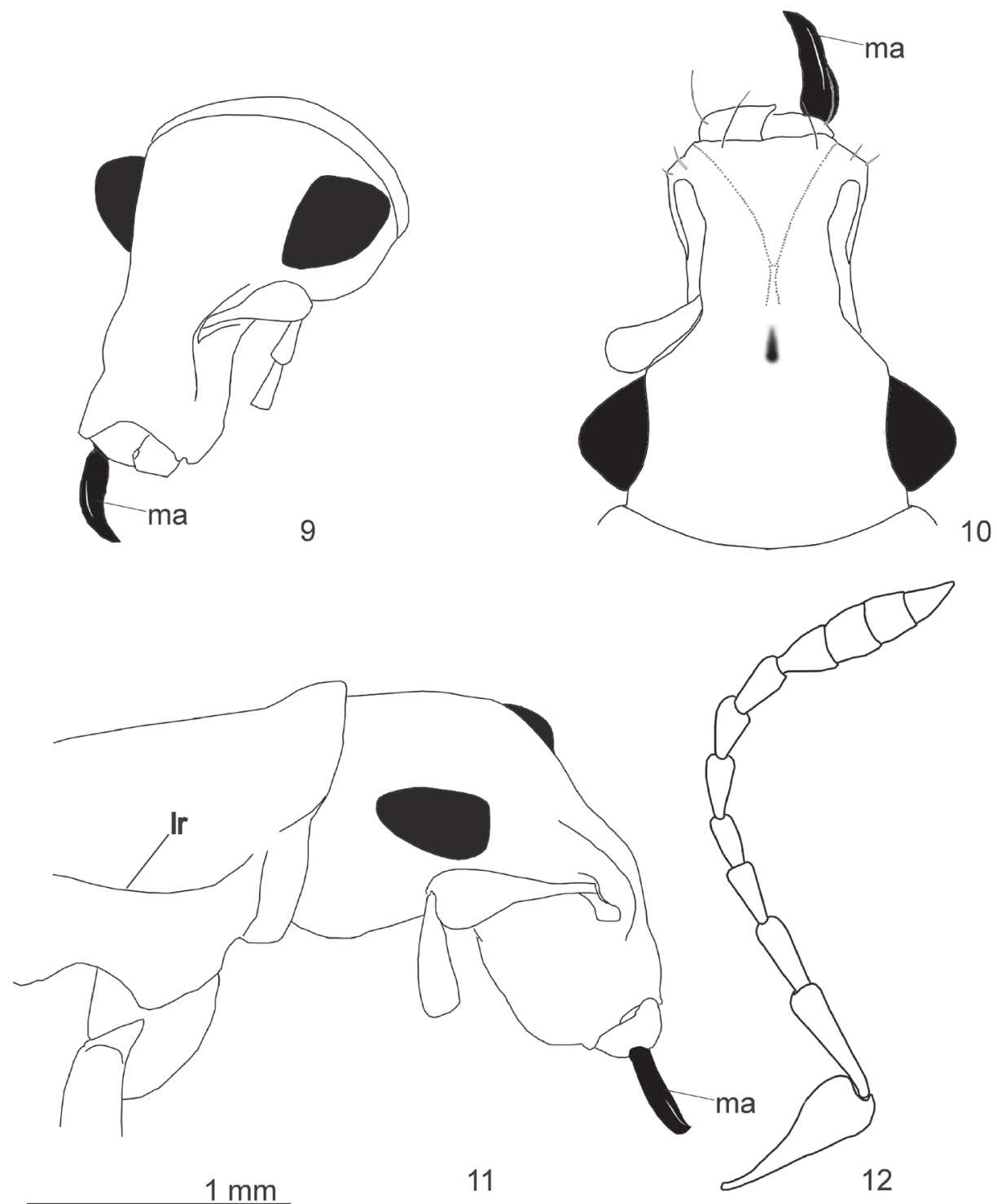

Figures 9-12. Arostropsis groehni gen. et sp.n. 9 head, antero-lateral view $\mathbf{I} \mathbf{~ i d e m , ~ a n t e r o - d o r s a l ~ v i e w ~ I ~ I ~}$ head and prothorax, lateral view $\mathbf{I} \mathbf{2}$ antenna, lateral view. Abbreviations: $\mathbf{l r}$ lateral ridge, ma mandibular process. Scale bar: $1 \mathrm{~mm}$.

Legs slender. Femora slender, elongate, obtuse, weakly swollen in apical third. Tibiae slender and elongate. Protibiae gently curved inwards in apical third; with anterior row of thin spines. Metatibiae subflattened and with inner edge sinuate at apical third. Corbels open (Figs 6, cb; 8), without additional row of spines. Tarsi slender, setaceous, pelma well-developed (term after Doyen 1966). Tarsomere 1 almost as long as 

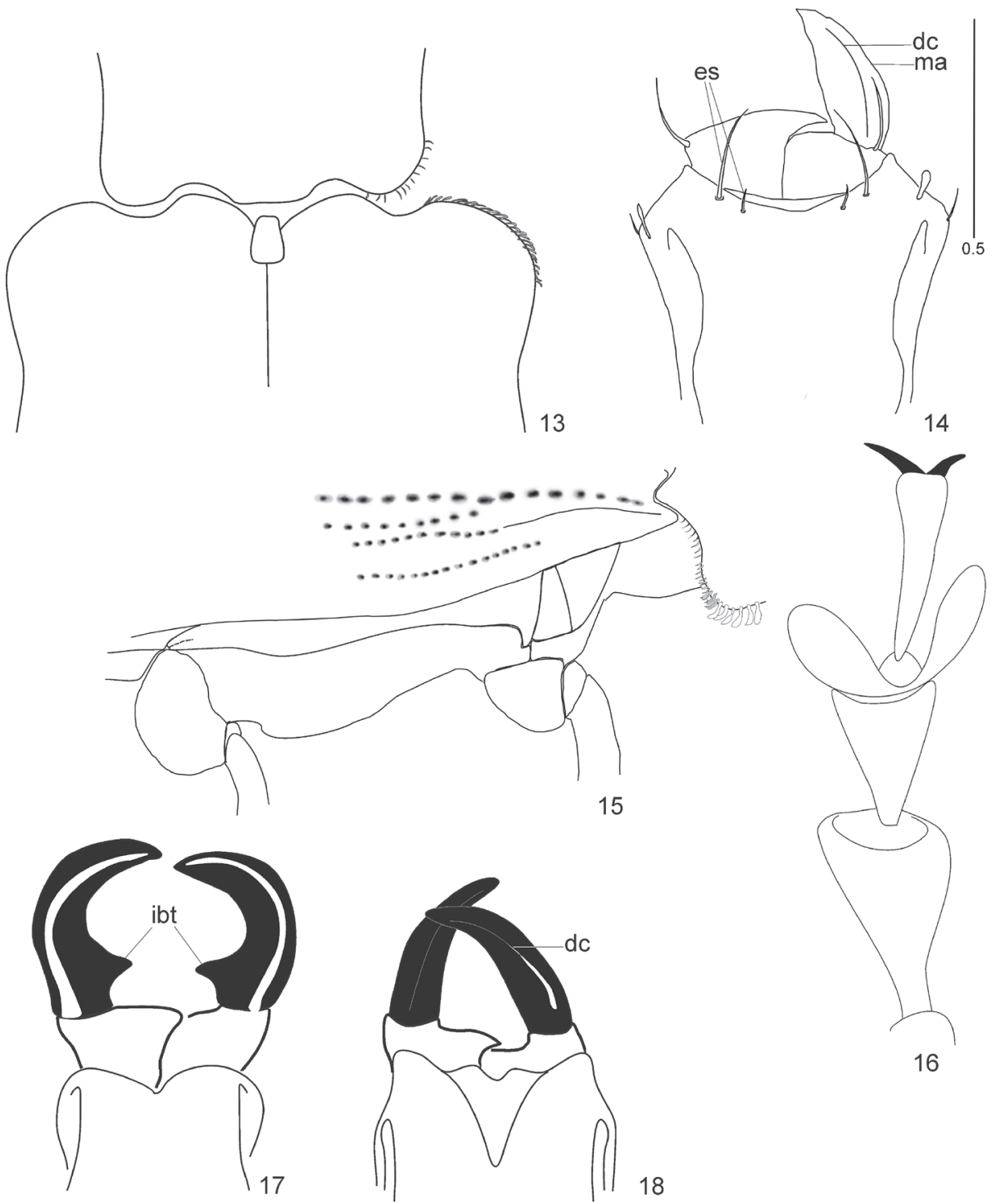

16

Figures 13-18. Species of Arostropsis, Lepropus, and Naupactus, details. Figs 17 and 18 (modified from Thompson, 1992). 13-16. Arostropsis groehni sp. n. I 3 base of pronotum and elytra $\mathbf{4}$ epistome $\mathbf{5}$ epi-

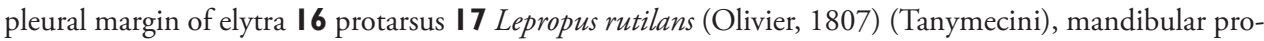
cesses dentate 18 Naupactus fatuus Boheman, 1833, mandibular processes simple (Naupactini). Abbreviations: dc dorsal carina of mandibular process, ibt interobasal tooth of mandibular process, es epistomal setae, ma mandibular process. Scale bar: $1 \mathrm{~mm}$ (Figs 13, 15); $0.5 \mathrm{~mm}$ (Figs 14, 16); not in scale (Figs 17, 18).

tarsomeres 2-3 combined. Ultimate tarsomere extended beyond lobes of tarsomere 3 by length of last one. Claws free. Procoxae comparatively small, situated in middle of prothorax (Fig. 8). 
Comparison with recent genera. The new genus differs from all recent genera of Naupactini with open corbels and procoxae not completely separated from the prosternum (Mesagroicus Schoenherr, 1840, Eurymetopus Schoenherr, 1840, Melanocyphus Jekel, 1875, Trichonaupactus Hustache, 1939 ) in the following characters: short and depressed scape, rostrum narrow, epistomal area weakly setose, epifrons with a weakly developed median depression and vertex with very small fossa, not continuing to occiput.

Comparison with Baltic amber entimine genera. Since Arostropsis gen. n. has free claws, only two other fossil genera, Paonaupactus Voss, 1953 and Protonaupactus Zherikhin, 1971, share the same character state and can be compared with the new genus. Arostropsis gen. n. strongly differs from both Paonaupactus and Protonaupactus in the following characters given in the key below.

\section{Key to Baltic amber genera of Entiminae with free claws}

$1 \quad$ Scape short, reaching middle of eyes, strongly thickened apically; pedicel 1.5 times as long as or $2^{\text {nd }}$ funicular article; $1^{\text {st }}$ article of club similar in shape and size with $7^{\text {th }}$ funicular article. Eyes irregularly convex, lateral, located significantly below level of frons (in lateral view). Epifrons without transverse sulcus before eyes. Lateral carina of prothorax developed. Pronotal disc depressed. Procoxae situated in middle of prosternum. Body length $6.4 \mathrm{~mm}$

Arostropsis gen. n.

- $\quad$ Scape long, reaching anterior edge of prothorax, not strongly thickened at apex; pedicel 0.7 time as long as $2^{\text {nd }}$ funicular article; $1^{\text {st }}$ article of club significantly different in shape from $7^{\text {th }}$ funicular article. Eyes evenly convex, dorso-laterally, located almost at level of frons and somewhat extended above level of frons (in lateral view). Epifrons with more or less developed, transverse sulcus before eyes. Sides of prothorax evenly swollen, without carina. Pronotal disc moderately convex. Procoxae are closer to the anterior than to the posterior edge of prosternum. Body length 4.0-4.8 mm....................... 2

2 Antennal club oval. 4.5-4.8 mm. .......... Protonaupactus Zherikhin, 1971

- $\quad$ Antennal club spindle-shaped. $4 \mathrm{~mm}$....................Paonaupactus Voss, 1953

\section{Systematic position}

This new genus is undoubtedly a member of Entiminae due to the presence of mandibular processes. Due to structural characters: mandibular processes long, knife-shaped (ibt not developed) - claws free, vertex and epifrons combined in uniform structure without transverse sulcus before eyes, the new genus could be assigned to the tribes Naupactini or Geonemini Gistel, 1848. Emden separated these groups from other 'brachyderoid' tribes of Entiminae with free claws (Tanymecini and Anypotactini) by the following characters (Table 1). 
Table I. Basic morphological characters of 'brachyderoid' tribes of Entiminae with free claws in comparison with the genus Arostropsis gen.n.

\begin{tabular}{l|l|l|l|l|l}
\hline & Geonemini & Naupactini & Tanymecini & Anypotactini & Arostropsis \\
\hline 1. Postocular vibrissae & absent & absent & present & absent & absent \\
\hline 2. Claws & free & free & free/connate & free & free \\
\hline 3.Transverse sulcus & absent & $\begin{array}{l}\text { present/ } \\
\text { absent }\end{array}$ & $\begin{array}{l}\text { present/ } \\
\text { absent }\end{array}$ & $\begin{array}{l}\text { present/ } \\
\text { obsolete }\end{array}$ & absent \\
\hline 4. Eyes position & dorso-lateral & lateral & dorso-lateral & dorso-lateral & lateral \\
\hline 5. Mentum covers maxillae & yes & yes & yes & yes/no & unknown \\
\hline 6. Metatibial corbels & open/enclosed & $\begin{array}{l}\text { open/ } \\
\text { enclosed }\end{array}$ & $\begin{array}{l}\text { open/ } \\
\text { enclosed }\end{array}$ & open & open \\
\hline 7. Mandibular processes & without ibt & without ibt & with ibt & unknown & without ibt \\
\hline 8. Procoxae position & anterior & $\begin{array}{l}\text { anterior/ } \\
\text { median }\end{array}$ & median & median & median \\
\hline
\end{tabular}

The position of Arostropsis is tested following the table:

Presumption 1 (Geonemini). Arostropsis gen.n. lacks the key characters of Geonemini such as: evenly sloping lateral edges of epifrons, very narrow vertex and anterior position of procoxae. Consequently this genus cannot be assigned to this tribe..

Presumption 2 (Tanymecini). Arostropsis gen. n. could not be considered in the tribe Tanymecini, due to absence of postocular vibrissae at the prothorax. The amount of vibrissae varies from genus to genus within Tanymecini but at least a few vibrissae are present (some Pandeleteius). We do not know any case in which vibrissae are completely absent, so it is unlikely that Arostropsis belongs to Tanymecini.

Presumption 3 (Anypotactini). Due to absence of transverse sulcus between vertex and epifrons and U-shaped epistome in Arostropsis it is impossible to consider this genus within Anypotactini.

Presumption 4 (Naupactini). The strictly lateral position of the eyes, flattened epifrons and very broad vertex resembles that of Arostropsis within Naupactini, however, the shape of the rostrum is very different from that of any known member of this tribe. This transformation of rostrum probably resulted in reduction of the frontal fossa (Fig. 10) that is normally (in genera with broad rostrum) deep, long and continuing from the anterior portion of epifrons to the occiput. Such head shape together with the unusual slender body makes it difficult to recognize Arostropsis as a member of the tribe Naupactini.

Probable bionomy. The long legs and well developed tarsal pelma (term after Doyen 1966) of the new species suggests that this beetle was capable of running swiftly between leaves and, therefore, it was likely a canopy-dweller.

\section{Genus Protonaupactus Zherikhin, 1971}

= Sucinophyllobius Wanat \& Borowiec, 1986: 243, syn. n.

Type species Sucinophyllobius viridis Wanat \& Boroviec, 1986 
Type species. Protonaupactus microphthalmus Zherikhin, 1971

Included species: Protonaupactus microphthalmus Zherikhin, 1971, P. viridis (Wanat \& Boroviec, 1986), comb. n., P. sobrinus (Voss, 1972), comb. n.

Protonaupactus sobrinus (Voss, 1972), comb. n.

http://species-id.net/wiki/Protonaupactus_sobrinus

Figs 19-34

Phyllobius sobrinus Voss 1972: 174

Sucinophyllobius sobrinus Wanat \& Borowiec 1986: 243

Material examined. Holotype: ZMUC903847, male (ZMUC); the complete beetle is included in a nearly regular amber piece, parallelepiped, with facets 14.0, 10.0 and $5.0 \mathrm{~mm}$; one thin layer with wavy, light organic matter, small gas bubbles and small cracks located beneath the beetle.

Type strata. Baltic Amber; Upper Eocene, Prussian Formation.

Type locality. Denmark "Bernschteinschluss, Versterhavet bei Thisted, 17.xii.1895, Madsen leg.".

Redescription. Length 4.5, width 1.75 , and height $1.65 \mathrm{~mm}$. Beetle densely covered with metallic, shining scales (apparently green).

Head. Rostrum 1.5 times as long as wide at level of pterygia. Epifrons subparallel-sided, at level of antennal insertions abruptly widened anteriorly, weakly convex longitudinally, separated from frons by a distinct depression indicating a transverse sulcus hidden by dense scales. Pterygia strongly extending beyond lateral contour of rostrum. Epistome well-defined by U-shaped keel. Epistomal setae grouped in dense bunches at anterior epistomal angles. Each bunch bearing at least 5 setae. Epistomal angles pronounced apically. Anterior edge of pterygia densely setose. Antennal furrows distinct only in their basal half and not continuing obliquely to underside of rostrum, their dorsal and ventral edges somewhat divergent posteriorly. Eyes dorso-lateral, round and evenly convex. Frons slightly convex, as wide as epifrons between antennal insertions. Frontal fossa not visible because masking by scales. Antennae long. Scape straight, evenly thickened apically, reaching anterior constriction of pronotum. Funicle thin: pedicel about 0.7 time as long as $2^{\text {nd }}$ funicular article; $2^{\text {nd }}$ article about 3.5 times as long as wide; $3^{\text {rd }}-7^{\text {th }}$ articles weakly oblong, about 1.5 times as long as wide. Club ovoid, about 2.3 times as long as wide, its $1^{\text {st }}$ article significantly different in shape from $7^{\text {th }}$ funicular article.

Pronotum transverse; evenly convex at sides and disc, strongly constricted anteriorly and posteriorly. Its base slightly bisinuate. Anterior edge of pronotum straight, without postocular lobes, spurs or vibrissae. Scutellum significantly pronounced, subquadrate.

Elytra subparallel, hardly widened in apical half, with pronounced humeral prominences. Epipleural edge weekly but distinctly S-shaped. Wings well-developed, beetle apparently capable of flying. Elytral declivity abruptly sloping. Anterior edge of anal ventrite (hypopygidium) emarginate (Fig. 30). 

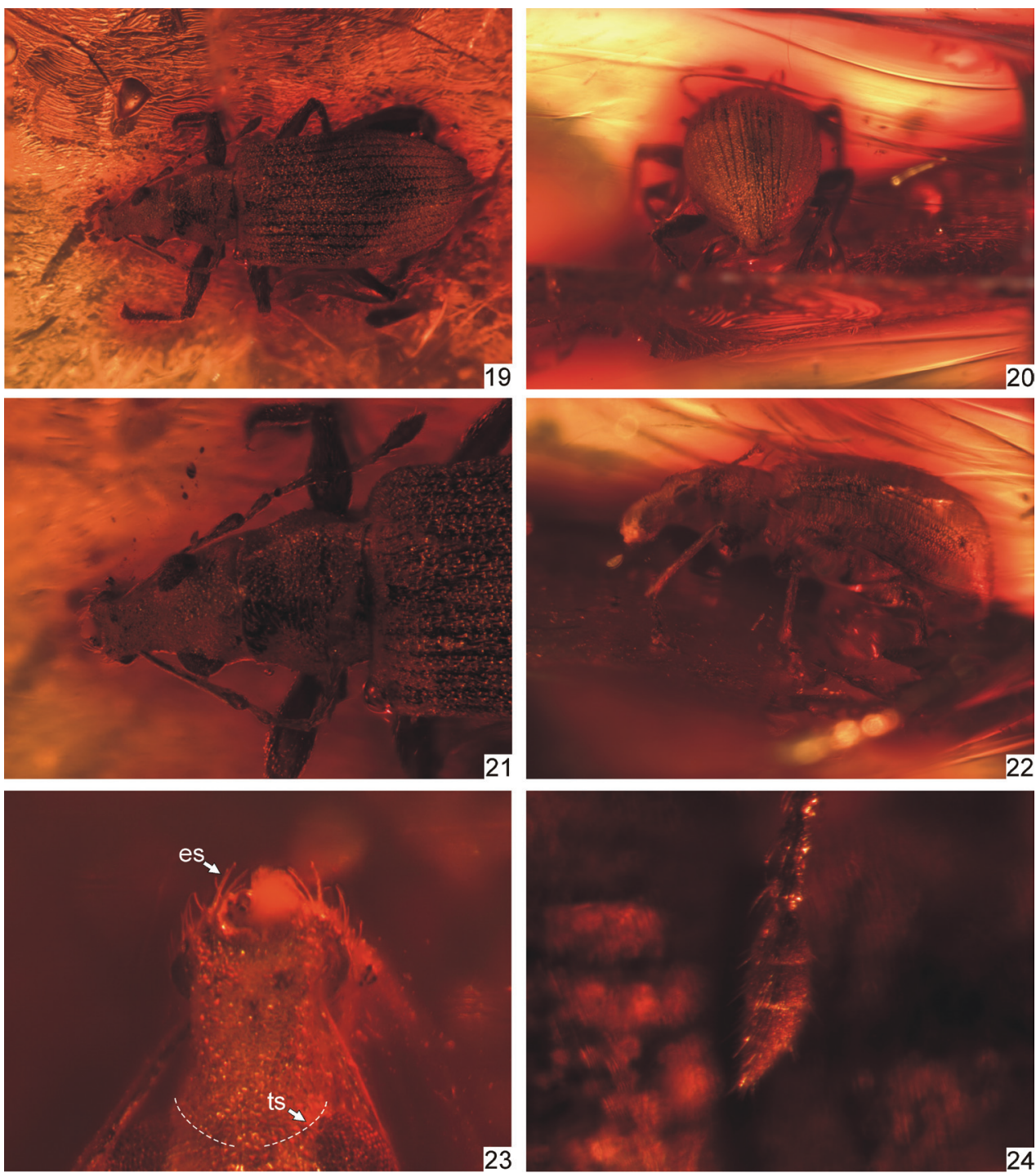

Figures 19-24. Protonaupactus sobrinus (Voss, 1972), holotype, male. 19 body, dorsal view 20 elytral declivity, posterior view $\mathbf{2} \mathbf{I}$ head and pronotum, dorsal view $\mathbf{2 2}$ body, lateral view $\mathbf{2 3}$ rostrum, dorsal view (transverse sulcus, indicated by dashed line, hidden by dense scale vestiture) $\mathbf{2 4}$ antennal club. Abbreviations: es epistomal setae, ts transverse sulcus. Body length: $4.5 \mathrm{~mm}$.

Legs thin. Femora obtuse, weakly swollen in middle part. Protibiae straight at external edge, not widened at external apical angle. Metatibiae spatulate apically (Fig. 33), with open corbel but without additional setal row. Setal comb of all tibiae weakly-developed. Tarsi with well-developed setaceous pelma (term after Doyen 1966). Tarsomere 1 about as long as tarsomeres 2 and 3 combined. Tarsomere 3 with well-developed lobes. Ultimate tarsomere by 0.7 extending beyond lobes of tarsomere 3. Claws free. 

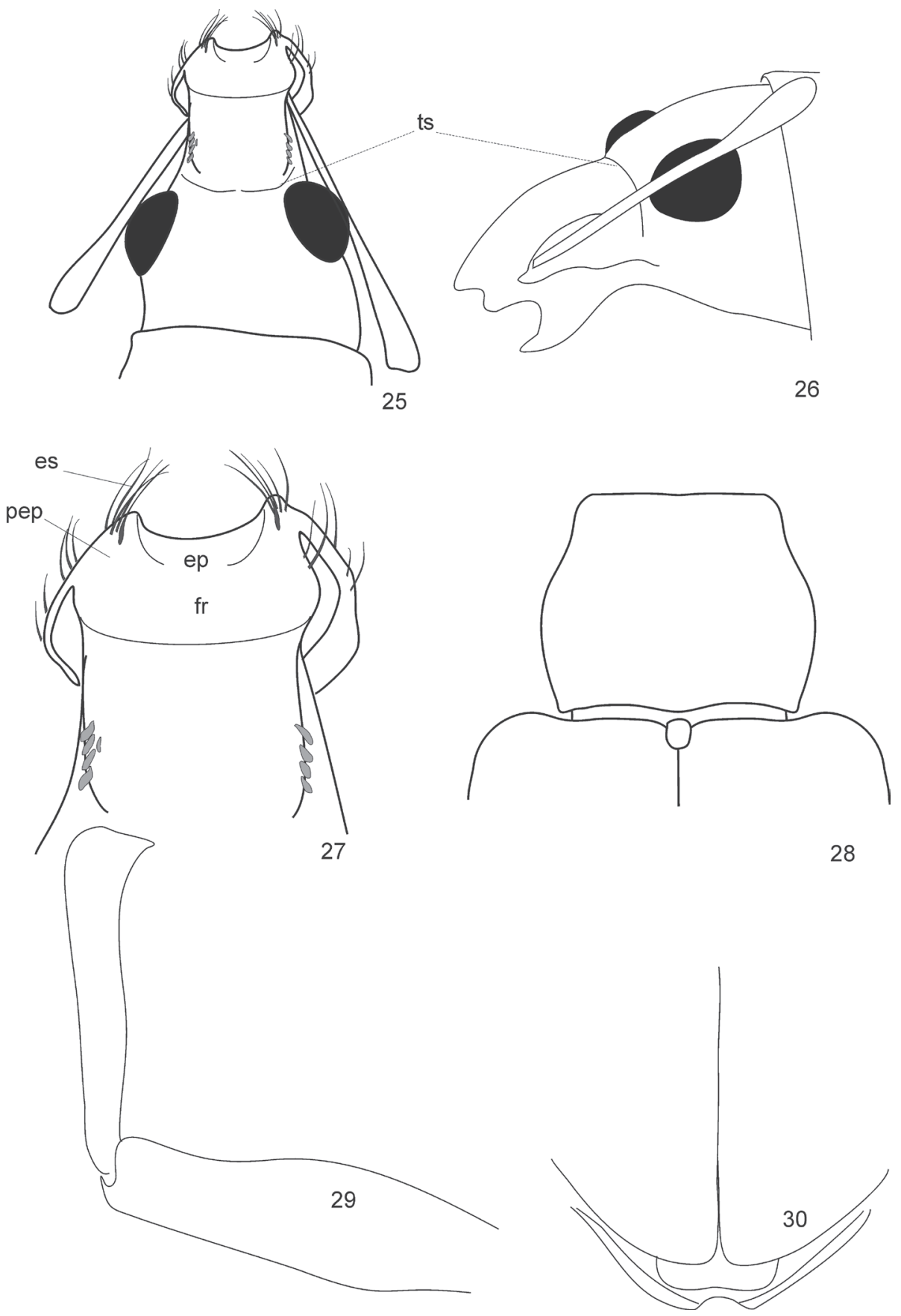

Figures 25-30. Protonaupactus sobrinus (Voss, 1972), holotype, male. 25 head with antennal scape, dorsal view $\mathbf{2 6}$ idem, lateral dorsal view $\mathbf{2 7}$ epistomal area of rostrum $\mathbf{2 8}$ pronotum and elytral base, dorsal view 29 anterior right leg, dorsal view $\mathbf{3 0}$ elytral apex with pygidium and anal ventrite. Abbreviations: ts transverse sulcus, es epistomal serae, ep epistome, fr frons, pep parepistome. Scale bar: $1 \mathrm{~mm}$ (Figs 25, 26, 28, 30); $0.5 \mathrm{~mm}$ (Figs 27, 29). 


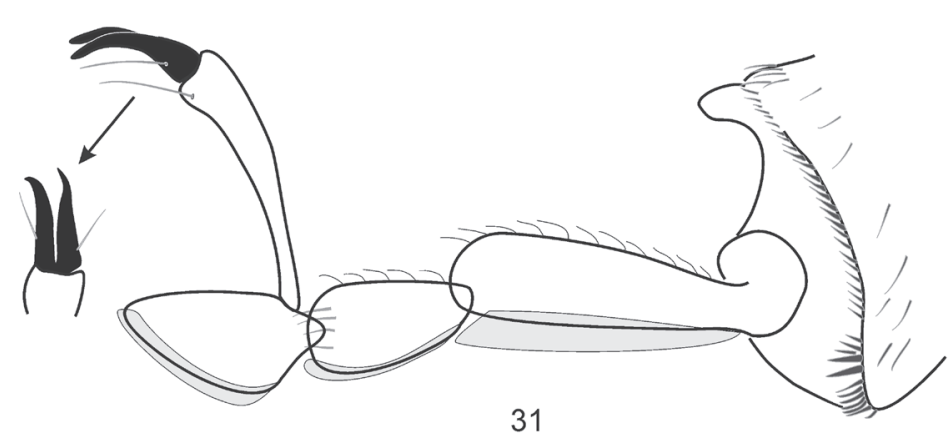

31
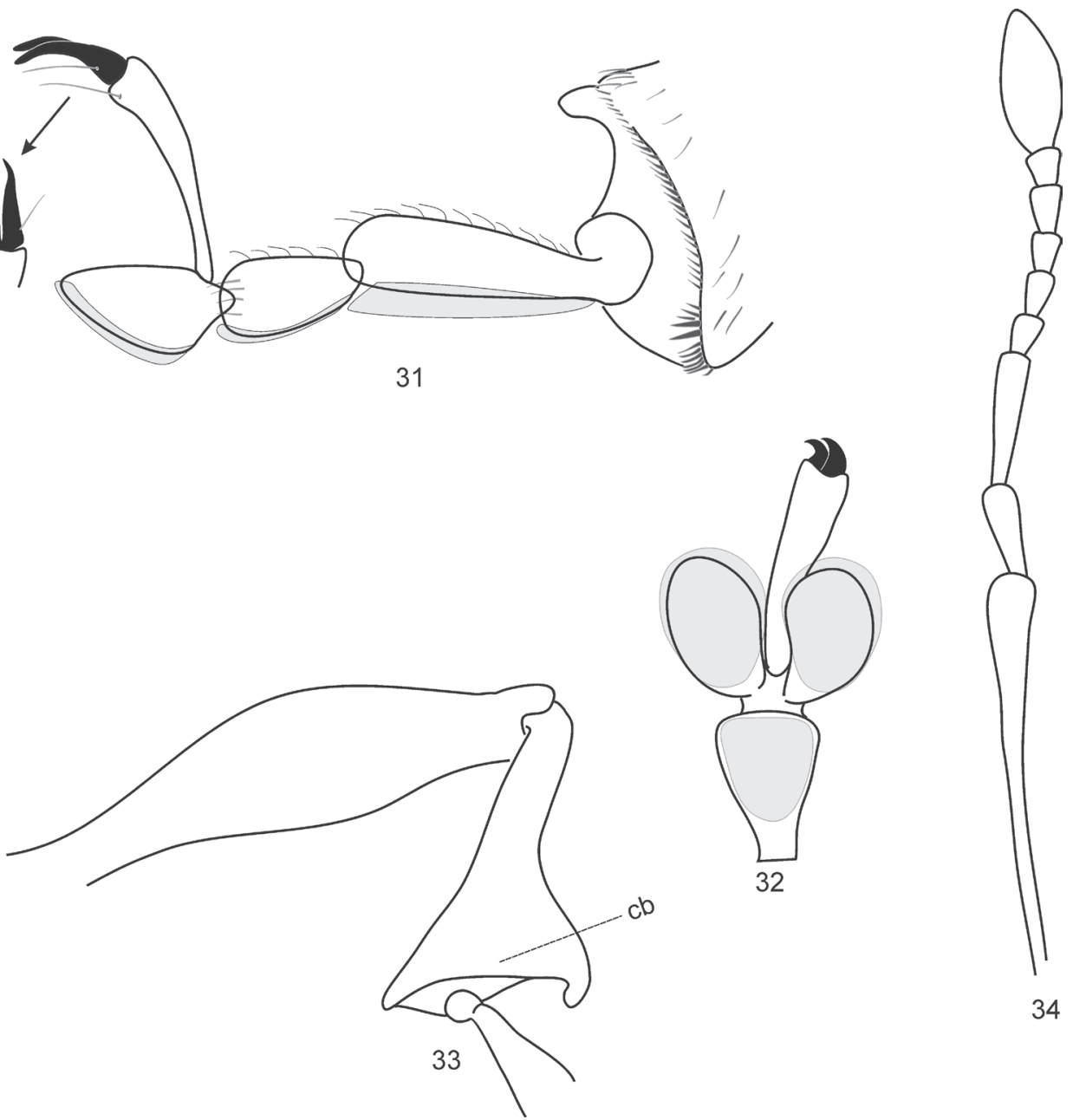

Figures 3 I-34. Protonaupactus sobrinus (Voss, 1972), holotype, male. 3 I metatibial apex and tarsus lateral view, and claws dorsal view $\mathbf{3 2}$ mesotarsus ventral view $\mathbf{3 3}$ posterior leg $\mathbf{3 4}$ antenna. Remark. Setose pelma (term after Doyen, 1966) indicated by grey color. Scale bar: $0.25 \mathrm{~mm}$ (Figs 31, 32); $0.5 \mathrm{~mm}$ (Figs 33, 34).

Differential diagnosis. This species is distinguished from P. microphthalmus and $P$. viridis by the metatibiae being strongly spatulate apically. The re-examination of the holotype of Phyllobius sobrinus Voss, 1972 demonstrates the particular structure of the head, which is very similar to some genera of Anypotactini (mostly from tropical America) and Cyphicerini (mostly from Old World tropics, distinctly separated groups): epistome U-shaped, convex, weakly sinuate anteriorly, and claws free (Figs 27, 31). This species also shares a well-developed, transverse sulcus on the rostrum (Fig. 25, 26, 35-39) with other groups of Anypotactini.

Notes on synonymy. The comparison of Sucinophyllobius sobrinus, S. viridis and Protonaupactus microphthalmus shows they are closely related species of the same genus. 

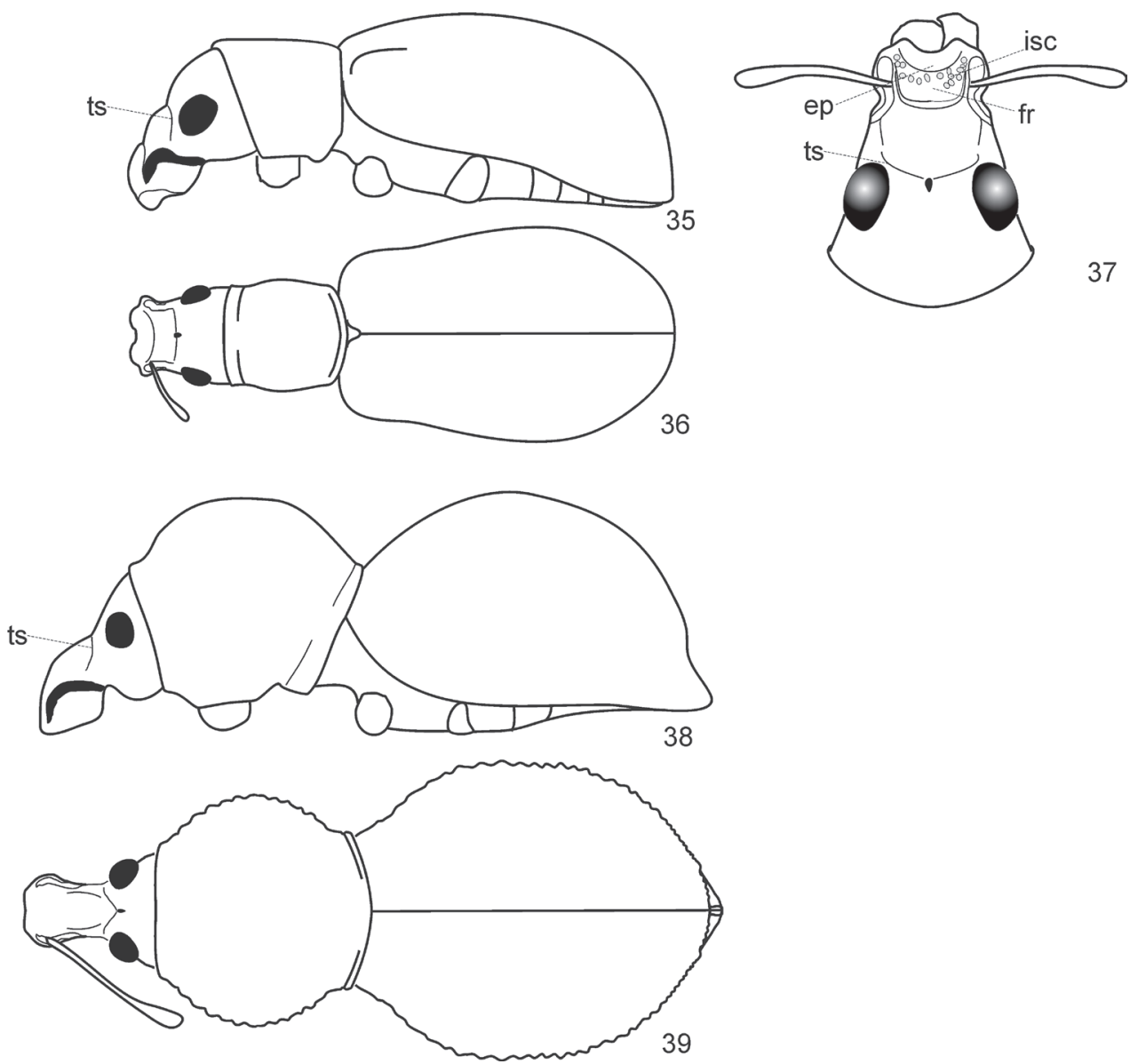

Figures 35-39. Anypotactini, details. 35, 38 body, lateral view; 36, 39 body, dorsal view; 37 head, dorsal view. 35-37 Anypotactus exilis Boheman, 1840, female (Venezuela); length 3,3 mm 38, 39 Hyphantus buccifer Germar, 1824, female (Brazil); length 8,2 mm. Abbreviations. isc incrustation scales, ep epistome, fr frons, ts transverse sulcus.

They share almost the same characters of the rostrum, with moderately defined Ushaped epistome having apically pronounced angles, long and slender antennae with the scape extending behind the anterior margin of the pronotum, funicular article 1 about $0.7 \times$ as long as article 2 , and article 2 about $3.5 \times$ as long as wide.

\section{Systematic position of Protonaupactus}

Anypotactini and Cyphicerini are the only tribes of Entiminae whose relationships with Protonaupactus still need to be tested. Both tribes contain genera with the following characters: (1) claws free, (2) epistome deeply sinuate, parepistome distinctly 
protruding and bearing dense bunches of long setae, (3) swinging fossae long, fully visible in dorsal view, (4) pterygia strongly extended beyond rostrum.

The tribe Cyphicerini consists of rather diverse genera which may be divided into two subgroups by the structure of the prothorax and underside of the head: (1) a prosternum subflattened with straight anterior edge; $\mathbf{b}$ pronotum with straight anterior edge; $\mathbf{c}$ rostrum and head united in a consolidated structure; $\mathbf{d}$ underside of rostrum densely covered with scales, its sculpture uniform; e rostrum directed forwards (Mylacorrhinina and Myllocerina) or (2) a prosternum with anterior edge sinuate; $\mathbf{b}$ pronotum with distinct postocular lobes; $\mathbf{c}$ head and rostrum distinctly separated by transverse constriction; $\mathbf{d}$ basal area of underside of rostrum with glabrous integument which has a bare stripe reaching the eyes; e rostrum directed downwards (Acanthotrachelina, Cyphicerina, and Phytoscaphina).

Anypotactini include a group of genera that share a character set characteristic of the subgroup I of Cyphicerini and distinct from this subgroup in the transverse sulcus on the rostrum. However, this tribe displays an enormous variety in rostrum shape, and also shows both dorsal and lateral positions of the antennal scape which is normally folded above the eyes, along the rostrum, or folded obliquely downwards in the scrobe if developed. Both the antennal scape and funicle are quite slender, hence the antennae resemble a brachyderoid rather than otiorhynchoid type, like in Cyphicerini.

Anypotactus Schoenherr 1840, Polydacrys Schoenherr, 1833 and other genera with short rostrum and large pterygia belong to Anypotactini subgroup 1, and Prepodellus Kirsch, 1867, Hyphantus Germar, 1824 and other genera with long rostrum with very small pterygia belong to Anypotactini subgroup 2.

Protonaupactus combines both character sets, Anypotactini and Cyphicerini. Nevertheless, it can be easily distinguished from Cyphicerini subgr. 2 in sharing the basic character set of Cyphicerini subgr. 1 and Anypotactini subgr. 1. From Cyphicerini subgr.1 Protonaupactus differs particularly in the transverse sulcus on the rostrum (Fig. $25,26)$. The new data on this fossil genus show that the distinctness between these tribes is not very clear and needs a further investigation.

\section{Acknowledgements}

The authors are pleased to express their gratitude to Carsten Gröhn (GPIH), who provided material for study. They also express sincere thanks to Lars Vilhelmsen and Alexey Solodovnikov (ZMUC) for the opportunity to examine the Baltic amber collection. Wolfgang Weitschat (GPIH) assisted to the authors in their attempts to seek the types of E. Voss which should be deposited in GPIH but now are missing. Steven R. Davis (University of Kansas, Lawrence), George Poinar Jr. (Oregon State University, Corvallis), and two anonymous referees made an essential contribution in improving the English and the content of the manuscript. The use of the data after Vladimir V. Zherikhin (published in Ponomarenko et al. 2011) greatly contributed to the fulfillment of this study. The first 
co-author was supported by the Deutsche Forschungsgemeinschaft grant: KL 1162/4-1, AOBJ 554623. The second co-author was supported by the Program of the Presidium of the Russian Academy of Sciences 'Origin of Biosphere and Evolution of Geo-Biological Systems' and Russian Foundation of Basic Research (grant 09-04-00789-a). The second co-author have also a pleasant duty to express his recognition to the Muséum national d'Histoire naturelle for providing him a possibility to work in this museum according to the program of visiting professors. The authors' work with the collection of ZIN was supported by the Russian Ministry of Education and Science.

\section{References}

Alonso-Zarazaga MA, Lyal ChHC (1999) A world catalogue of families and genera of Curculionoidea (Insecta: Coleoptera) (excepting Scolytidae and Platypodidae) Entomopraxis, Barcelona, $315 \mathrm{pp}$.

Burmeister H (1831-1832) Handbuch der Entomologie. Band I. G. Reimer, Berlin, xvi + 696 pp. Emden F van (1944) A key to the genera of Brachyderinae of the world. Annals and Magazine of Natural History 11(11): 503-532, 559-586. doi: 10.1080/00222934408527452

Doyen JT (1966) The Skeletal Anatomy of Tenebrio molitor (Coleoptera: Tenebrionidae). Miscellaneous publications of the Entomological Society of America 5(3): 103-150.

Germar EF (1849) Über einige Insekten aus Tertiargebildungen. Zeitschrift der Deutschen geologischen Gesellschaft 1: 52-66.

Giebel CGA (1856) Analyse von Berendt, Die im Bernstein befindlichen organischen Reste der Vorwelt. Band 2. Zeitschrift für die gesamte Naturwissenschaft 8: 619-624.

Heer O (1847) Die Insektenfauna der Tertiärgebilde von Oeningen und von Radoboj in Croatien. Erste Abtheilung: Käfer. Neue Denkschriften der Allgemeinen Schweizerischen Gesellschaft für die gesamten Naturwissenschaften 8: 1-229 + index + 8 pl. [own pag.]

Heer O (1864-1865) Die Urwelt der Schweiz. Parts 1 to 11 . Druck und Verlag von Friedrich Schulthess, Zürich, xxix +622 pp. +11 pl +1 map. [Published in parts; according to Evenhuis, 1997-352, these are: (1-2): pp. 1-96, pi 1-6, before 30-III-1864; (3-4): pp. 97-192, pl. 7 , 30-III-1864; (5-6): pp. 193-288, pl. 8, between 31-III and 17-VIII-1864; (7-11): pp. 289496, pl. 9-10, 18-VIII-1864; (12-13): pp. i-xxix + 497-622 + pl. 11, between I and VI-1865]

Hieke F, Pietrzeniuk E (1984) Die Bernstein-Käfer des Museums für Naturkunde, Berlin (Insecta, Coleoptera). Mitteilungen aus dem Zoologischen Museum in Berlin 60(2): 297-326.

Hundsdoerfer AK, Rheinheimer J, Wink M (2009) Towards the phylogeny of the Curculionoidea (Coleoptera): Reconstructions from mitochondrial and nuclear ribosomal DNA sequences. Zoologischer Anzeiger 248: 9-31. doi: 10.1016/j.jcz.2008.09.001

Kirejtshuk AG, Kurochkin AS (2010) New Species of Sap Beetles (Coleoptera: Nitidulidae: Nitidulini) from the Baltic and Bitterfeld Ambers. Paleontological Journal 44(1): 53-67.

Kissinger DG (1973) A new weevil genus from America north of the Arctic Circle and notes of fossils from Pliocene and Pleistocene sediments (Coleoptera: Curculionidae). Coleopterists Bulletin 27(4): 193-200. doi: 10.1134/S0031030110010089 
Klebs R (1910) Über Bernstein einschlüsse im allgemeinen und die Coleopteren meiner Bernsteinsammlung. Schriften der Physikalisch-Ökonomischen Gesellschaft zu Königsberg 51(3): 217-242.

Morimoto K, Kojima H, Miyakawa S (2006) The insects of Japan. Volume 3. Curculionoidea: general introduction and Curculionidae: Entiminae (part 1). Phyllobiini, Polydrusini and Cyphicerini (Coleoptera). Touka Shobo Co. Ltd., Fukuoka, iv + 406 pp.

Oberprieler RG (2010) A reclassification of the weevil subfamily Cyclominae (Coleoptera: Curculionidae). Zootaxa 2515: 1-35.

Poinar G Jr., Brown AE (2011) Descriptions of a broad-nosed weevil (Eudiagogini: Curculionidae) and false ladybird beetle (Nilionini: Nilionidae) in Dominican amber. Historical Biology, 23 (2): 231-235. doi: 10.1080/08912963.2010.527159

Ponomarenko AG, Zherikhin VV, Kirejtshuk AG (2011) Catalogue of fossil Coleoptera. http:// www.zin.ru/Animalia/Coleoptera/rus/paleosys.htm [accessed 1.III.2011]

Serres M de (1829) Gèognosie des Terrains Tertiaires, ou Tableau des principaux animaux invertébrés des terrains marins tertiaires, du midi de la France. Pomathio-Durville, ParisMontpellier, 277 pp.

Spahr U (1981) Systematischer Katalog der Bernstein- und Kopal-Käfer (Coleoptera). Stuttgarter Beiträge zur Naturkunde 80: 1-107.

Takhtajan AL (1970) Proiskhozhdenie i rasprostranenie zvetkovykh rasteniy [Origins and Dispersion of Flowering Plants]. Nauka, Leningrad, 1-146. [in Russian]

Thompson RT (1992) Observations on the morphology and classification of weevils (Coleoptera, Curculionoidea) with a key to major groups. Journal of Natural History 26: 835-891. doi: 10.1080/00222939200770511

Voss E (1953) Einige Rhynchophoren der Bernsteinfauna (Col.). Mitteilungen aus dem Geologischen Staatsinstitut in Hamburg 22: 119-140.

Voss E (1972) Einige Rüsselkäfer der Tertiarzeit aus Baltischem Bernstein (Coleoptera, Curculionoidea). Steenstrupia 2(11): 167-181.

Wanat M, Boroviec L (1986) New genus of weevil (Coleoptera, Curculionidae) from Baltic amber. Polskie Pismo Entomologiczne 56(2): 243-247.

Zherikhin VV (1971) O dolgonosikach (Insecta, Coleoptera) Baltiyskogo Jantarja [On the weevils (Insecta, Coleoptera) from the Baltic Amber]. Trudy Palaeontologicheskogo Instituta 130:197-209.

Zherikhin VV (1992) Tertiary weevils (Insecta, Coleoptera: Curculionoidea), identified from the collections of the Senckerberg Museum. Senckerbergiana Lethaea 72: 169-178.

Zherikhin VV, Egorov AB (1991) Weevils (Coleoptera, Curculionidae) of the USSR Far East (a review of the subfamilies with description of new taxa). Institute of Biology and Soil science, Vladivostok, 164 pp. [in Russian] 


\section{Appendix}

\section{Checklist of prepleistocene fossil weevils of the subfamily Entiminae}

(according to the taxonomic interpretation in Zherikhin and Egorov 1991 and Ponomarenko et al. 2011)

V.V. Zherikhin analyzed all available sources mentioning fossil Curculionoidea (Jurassic-Paleogene). Later the results of his analysis were published in the catalogue by Ponomarenko et al. (2011). In the list below (Table 1) the authors mostly follow his subdivisions pertaining to the subfamily Entiminae. Many references in the list provided here need to be checked re-examining the fossils. Most accounts regarded as doubtful Zherikhin were removed from the following list. Ponomarenko et al. (2011) treated them as 'Subfamilia incerta' or 'Familia incerta'.

Table 2. Checklist of prepleistocene fossil Entiminae.

Subfamilia Entiminae Schoenherr, 1823

\begin{tabular}{|c|c|c|}
\hline NN & Species & $\begin{array}{l}\text { age and site } \\
\text { of finding }\end{array}$ \\
\hline \multicolumn{3}{|c|}{ Tribe Aterpini Lacordaire, 1863 (see note 1 below this table) } \\
\hline 1 & Genus incertus fossicius Scudder, 1893:75 (Geralophus) & Pg31, Flor \\
\hline \multicolumn{3}{|c|}{ Tribe Tropiphorini Marseul, 1863} \\
\hline 2 & Vitavitus thulius Kissinger, 1973 & N2, Dece \\
\hline 3 & $\begin{array}{l}\text { Rhytideres sexsulcatus (Heer, 1856) (Cleonus) (= Hipporhinus reynesii Oustalet, } \\
\text { 1874; Brachycerus annosus Oustalet, 1874) }\end{array}$ & $\begin{array}{l}\text { Pg31st, Aix } \\
\text { N13, Agri }\end{array}$ \\
\hline \multicolumn{3}{|c|}{ Tribe Cylydrorhinini Lacordaire, 1863} \\
\hline 4 & Dorotheus guidensis Kuschel, 1959 & K2, CerG \\
\hline \multicolumn{3}{|c|}{ Tribe Sitonini Gistel, 1848} \\
\hline 5 & Sitona (subgenus incertus) lata Théobald, 1937 & $\begin{array}{l}\text { ?Pg31, } \\
\text { unknown }\end{array}$ \\
\hline 6 & Sitona (subgenus incertus) sp. (Hieke and Pietrzeniuk, 1984) & Pg23, BalJ \\
\hline \multicolumn{3}{|c|}{ Tribe Entimini Schoenherr, 1823} \\
\hline 7 & Geralophus antiquarius Scudder, 1893 & Pg31, Flor \\
\hline 8 & Geralophus occultus (Scudder, 1876) (Eurhinus) & Pg31, Flor \\
\hline 9 & Geralophus lassatus Scudder, 1893 & Pg31, Flor \\
\hline 10 & Geralophus scudderi Wickham, 1911 & Pg31, Flor \\
\hline 11 & Eudomus robustus Scudder, 1893 & Pg31, Flor \\
\hline 12 & Eudomus pinguis Scudder, 1893 & Pg31, Flor \\
\hline 13 & Hipporhinops sternbergi Cockerell, 1926 & Pg12, Sunc \\
\hline 14 & Genus incertus saxatilis Scudder, 1876 (Eudiagogus) & Pg22, GreR \\
\hline 15 & Genus incertus effossus Scudder, 1876 (Eudiagogus) & Pg22, GreR \\
\hline 16 & Genus incertus compactus Scudder, 1878: 765 (Ophryastes) & Pg22, GreR \\
\hline 17 & $\begin{array}{l}\text { Genus incertus heeri Germar, } 1849 \text { (Hipporhinus) (= matheroni Nicolas, 1891; } \\
\text { similis Nicolas, 1891; intermedius Nicolas, 1891; marioni Nicolas, 1891; pertonii } \\
\text { Nicolas, } 1891 \text { (Hipporhinus)) }\end{array}$ & Pg31, Aix \\
\hline 18 & Genus incertus brevis Giebel, 1856 (Hipporhinus) & Pg31, Aix \\
\hline 19 & Genus incertus schaumi Heer, 1856 (Hipporhinus) & Pg31, Aix \\
\hline
\end{tabular}




\begin{tabular}{|c|c|c|}
\hline NN & Species & $\begin{array}{l}\text { age and site } \\
\text { of finding }\end{array}$ \\
\hline 20 & Genus incertus pumiceus Scudder, 1893 (Geralophus) & Pg31, Flor \\
\hline 21 & Genus incertus repositus Scudder, 1893 (Geralophus) & Pg31, Flor \\
\hline 22 & Genus incertus atavus Oustalet, 1870 (Bagous) & Pg33, Core \\
\hline \multicolumn{3}{|c|}{ Tribe Tanymecini Lacordaire, 1863 (see note 2 below this table) } \\
\hline 23 & Genus incertus rugosus Deichmüller, 1881 (Thylacites) & $\mathrm{Pg} 3, \mathrm{Kucl}$ \\
\hline 24 & $\begin{array}{l}\text { Protainophthalmus asperulus (Heer, 1856) (Cleonus) (including Théobald, 1937) } \\
\text { (= Brachyderes aquisextanus Oustalet, 1874, B. longipes Heer in Oustalet, 1874, } \\
\text { Cleonus marcelli Oustalet, 1874) }\end{array}$ & $\begin{array}{l}\text { Pg31, Aix, } \\
\text { Cere }\end{array}$ \\
\hline 25 & $\begin{array}{l}\text { Protainophthalmus margarum (Germar, 1849) (Sitona) } \\
\text { (=antiqua Giebel, 1856) (Sitona) }\end{array}$ & Pg31, Aix \\
\hline 26 & Protainophthalmus punctulatus (Nicolas, 1891) (Desmidophorus) & Pg31, Aix \\
\hline 27 & Protainophthalmus regularis (Nicolas, 1891) (Hipporhinus) & Pg31, Aix \\
\hline 28 & Protainophthalmus rugicollis (Heer, 1847) (Lixus) & N13, Oeni \\
\hline 29 & Protainophthalmus thaisi Nicolas, 1891 (Desmidophorus) & Pg31, Aix \\
\hline 30 & Protainophthalmus tuberculatus Nicolas, 1891 (Desmidophorus) & Pg31,Aix \\
\hline 31 & Lepropus sp. (Zherikhin, 1992) & N13, Agri \\
\hline 32 & Genus incertus nudus Wickham, 1912 (Pandeleteius) & Pg31, Flor \\
\hline 33 & Genus incertus secunda Wickham, 1912 (Paussopsis) & Pg31, Flor \\
\hline \multicolumn{3}{|c|}{ Tribe Phyllobiini Schoenherr, 1826} \\
\hline \multirow[t]{2}{*}{34} & Phyllobius sp. (Spahr, 1981; Hieke and Pietrzeniuk, 1984 etc.) & Pg23, BalJ \\
\hline & Tribe Polydrusini Schoenherr, 1823 (see note 3 below this table) & \\
\hline 35 & Polydrusus (Palaeodrosus) archetypus Zherikhin, 1971 & Pg23, BalJ \\
\hline 36 & $\begin{array}{l}\text { Polydrusus (Subgenus incertus) sp. (Burmeister, 1832; Hieke and Pietrzeniuk, } \\
\text { 1984) }\end{array}$ & Pg23, BalJ \\
\hline \multicolumn{3}{|c|}{ Tribe Anypotactini Champion, 1911} \\
\hline 37 & $\begin{array}{l}\text { Paonaupactus sitonitoides Voss, } 1953 \text { (=Polydrusus scheelei Voss, 1953; Otiorhynchus } \\
\text { pellucidipes Voss, 1972) }\end{array}$ & Pg23, BalJ \\
\hline 38 & Paonaupactus cephalotes (Voss, 1972) (Phyllobius) & Pg23, BalJ \\
\hline 39 & Protonaupactus microphthalmus Zherikhin, 1971 & Pg23, BalJ \\
\hline 40 & $\begin{array}{l}\text { Protonaupactus sobrinus (Voss, 1972) (Phyllobius sbg. Subphyllobius); Wanat et } \\
\text { Borowiec, } 1986 \text { (Sucinophyllobius) }\end{array}$ & Pg23, BalJ \\
\hline 41 & Protonaupactus viridis (Wanat et Borowiec, 1986) (Sucinophyllobius) & Pg23, BalJ \\
\hline \multicolumn{3}{|c|}{ Tribe Hormorini Horn, 1876 (see note 4 below this table) } \\
\hline 42 & $\begin{array}{l}\text { Hormorus undulatus (Uhler, 1855) (Chlorophanus) (Alonso-Zarazaga and Lyal, } \\
\text { 1999) }\end{array}$ & N1, USA \\
\hline \multicolumn{3}{|c|}{ Tribe Pristorhynchini Heer, 1847 (Pristorhynchiden) } \\
\hline 43 & Pristorhynchus ellipticus Heer, 1847 & N13, Oeni \\
\hline \multicolumn{3}{|c|}{ Tribe Naupactini Gistel, 1856} \\
\hline 44 & Genus incertus florissantensis Wickham, 1914 (Cyphus) & Pg31, Flor \\
\hline 45 & Genus incertus subterraneus Wickham, 1911 (Cyphus) & Pg31, Flor \\
\hline \multicolumn{3}{|c|}{ Tribe Otiorhynchini Schoenherr, 1826} \\
\hline 46 & Otiorhynchus boettingensis van Emden in Zeuner, 1931 & N13, Boet \\
\hline \multicolumn{3}{|c|}{ Tribe Trachyphloeini Lacordaire, 1863} \\
\hline 47 & Trachyphloeus sp. (Klebs, 1910) & Pg23, BalJ \\
\hline \multicolumn{3}{|c|}{ Tribe Eudiagogini LeConte, 1874} \\
\hline 48 & Promecops tumidirostris Poinar et Brown, 2011 & N11, DomJ \\
\hline
\end{tabular}




\begin{tabular}{|c|c|c|}
\hline NN & Species & $\begin{array}{l}\text { age and site } \\
\text { of finding }\end{array}$ \\
\hline 49 & Laccopygus nilesii Scudder, 1893 & Pg31, Flor \\
\hline 50 & Evopes veneratus Scudder, 1893 & Pg31, Flor \\
\hline 51 & Oligocryptus sectus (Scudder, 1893) (Eucryptus) & Pg31, Flor \\
\hline 52 & Genus incertus atavina Heer, 1847 (Sitona) & N13, Oeni \\
\hline 53 & Genus incertus crassirostris Heer, 1864 (Naupactus) & N13, Oeni \\
\hline 54 & Genus incertus dilapsus Scudder, 1893 (Phyxelis) & Pg22, GreR \\
\hline 55 & Genus incertus durus Scudder, 1893 (Cryptorhynchus) & Pg22, RoaM \\
\hline 56 & Genus incertus eradicatus Scudder, 1893 (Phyxelis) & Pg22, RoaM \\
\hline 57 & Genus incertus evanidus Scudder, 1893 (Omileus) & Pg31, Flor \\
\hline 58 & Genus incertus evigoratus Scudder, 1893 (Phyxelis) & Pg22, WhiR \\
\hline 59 & Genus incertus exanimis Scudder, 1876 (Eudiagogus, Epicaerus) & Pg22, GreR \\
\hline 60 & Genus incertus fortis Cockerell, 1909 (?Syntomostylus) & Pg22, GreR \\
\hline 61 & Genus incertus manderstjernai Heyden et Heyden, 1866 (Tychius) & N11, Rott \\
\hline 62 & Genus incertus margarum Theobald, 1937 (Sitona) $[\mathrm{HN}]$ & Pg23, Cela \\
\hline 63 & Genus incertus obdurefactus Scudder, 1893 (Exomias) & Pg22, RoaM \\
\hline 64 & Genus incertus occubatus Scudder, 1893 (Evopes) & Pg31, Flor \\
\hline 65 & Genus incertus perditus Scudder, 1876 (Otiorhynchus) & Pg22, GreR \\
\hline 66 & Genus incertus petrarum Scudder, 1893 (Ophryastes) & Pg22, RoaM \\
\hline 67 & Genus incertus recuperatus Scudder, 1893 (Lachnopus) & Pg31, Flor \\
\hline 68 & Genus incertus rhenanus Meuner, 1923 (Laccopygus) & N11, Rott \\
\hline 69 & Genus incertus subteractus Scudder, 1893 (Otiorhynchus) & Pg22, RoaM \\
\hline 70 & Genus incertus subterraneus Scudder, 1893 (Scythropus) & $\begin{array}{l}\text { Pg22, GreR, } \\
\text { WhiR }\end{array}$ \\
\hline 71 & Genus incertus terrosus Scudder, 1878 (Eudiagogus) & $\begin{array}{l}\text { Pg22, RoaM, } \\
\text { WhiR }\end{array}$ \\
\hline 72 & Genus incertus venustulus Heyden et Heyden, 1866 (Sitona) & N11, Rott \\
\hline 73 & Genus incertus sp. (Serres, 1829) (Naupactus) & Pg31, Aix \\
\hline
\end{tabular}

Notes to table 2 .

1. In contrast to the interpretations of Zherikhin, the tribe Aterpini is traditionally treated as belonging to the subfamily Cyclominae (Alonso-Zarazaga and Lyal 1999, Oberprieler 2010, Bouchard et al. 2011) [in the classification proposed by Zherikhin and Egorov (1991) it is considered in 'Tropiphorinae']. Alonso-Zarazaga and Lyal (1999) consider the genus Hipporhinops in the subfamily Cyclominae.

2. According to V.V. Zherikhin's unpublished data, genus Protainophthalmus Zherikhin, 1992 comprises 7 species originally described within 'Cleonus', 'Sitona', 'Desmidophorus', 'Hipporhinus' and 'Lixus' from the Late Paleogene of France and Germany. Protainophthalmus asperulus (Heer, 1856) known by three type prints (see Oustalet 1874: 259-263 + plate 3: Figs 20 and 21), two of them (from Aix) are types. We consider they belong to different species or even different genera: since the first print (see Oustalet 1874: Fig. 20) has a transverse sulcus behind the epifrons, but the second print (Oustalet 1874: Fig. 20) does not have such a transverse sulcus. The original description of Protainophthalmus (Zherikhin 1992 : 174) also includes two prints 
(SMF VI 218 and SMF VI 220, Senckenberg Museum) from Agrigento (Italy) which are not types of $P$. asperulus.

3. The genus Phyllobius Germar, 1824 could not be placed in Polydrusini because of significant differences in head structure: long and closed swinging fossae, antennal scrobes not developed (foveiform) and scape not folding while in rest. V.V. Zherikhin, proposed that the tribes Polydrusini and Phyllobiini are synonyms. He considered that the number of mandibular setae is constant and may be used for discrimination of suprageneric groups (Zherikhin and Egorov 1991). Further study of Polydrusini and Phyllobiini genera showed a great variety of the number of mandibular setae. Recent molecular analysis based on two genes 16S rDNA and 18S rDNA, showed that Polydrusini and Phyllobiini are nested in different branches (Hundsdoerfer et al. 2009).

4. According to the current interpretation, the tribe Hormorini is assigned to Entiminae (Alonso-Zarazaga and Lyal 1999). This opinion corresponds to the results of our examination of mandibles, which revealed similarity between Hormorus and the North-Pacific genus Byrsopages Schoenherr, 1842. The abnormal shape of the mandibles, subflattened dorso-ventrally along the anterior edge and ventral position of the mandibular processes, led Zherikhin to refuse this opinion, and he treated Hormorus without subfamily placement as 'subfamilia incerta'. 